Dikirim: 28 Februari 2017 Diterbitkan: 1 Agustus 2017

\section{Dukungan keluarga dan kualitas hidup penderita stroke pada fase pasca akut di Wonogiri}

\author{
Family support and quality of life for stroke patients in the \\ post-acute phase of Wonogiri \\ Rahman $^{1}$, Fatwa Sari Tetra Dewi ${ }^{2}$, Ismail Setyopranoto ${ }^{3}$
}

\begin{abstract}
Purpose: This research aimed to determine the relationship of family support such as emotional, information, instrumental and reward with the quality of stroke patients in the post-acute phase in Wonogiri. Methods: A cross-sectional study was conducted involving interviews and the use of medical record data of 161 post-acute stroke patients in Wonogiri. Results: This study showed that there was a significant correlation of information support $(p=0.000)$, and awareness support $(p=0.000)$ with the quality of life of post-acute stroke patients. Conclusion: The study confirms the importance of family support in terms of information support and awards support to the quality of life of patients with post-acute stroke.
\end{abstract}

Keywords: family support; quality of life; post acute stroke

\footnotetext{
${ }^{1}$ Departemen Biostatistik, Epidemiologi, dan Kesehatan Populasi, Fakultas Kedokteran, Universitas Gadjah Mada (Email: rahman25058@mail.ugm.ac.id)

${ }^{2}$ Departemen Perilaku Kesehatan, Lingkungan dan Kedokteran Sosial, Fakultas Kedokteran, Universitas Gadjah Mada

${ }^{3}$ Departemen Ilmu Penyakit Syaraf, Fakultas Kedokteran, Universitas Gadjah Mada
} 


\section{PENDAHULUAN}

Stroke merupakan penyebab kematian ketiga di dunia setelah penyakit jantung dan kanker. Setiap tahun, diperkirakan kematian akibat stroke sekitar 5.540.000 kematian di seluruh dunia, dan dua pertiga dari kematian terjadi di negara kurang berkembang (1). Penelitian epidemiologi stroke di Asia Timur, selama tahun 1984-2004, menemukan angka kejadian kasus 4.995 di China, Taiwan dan Jepang. Sementara tahun 2005 dilaporkan prevalensi stroke sebesar 4,05\% di Singapura, sedangkan di Thailand prevalensi Stroke sebesar 690 per 100.000 penduduk (2).

Sebuah penelitian di beberapa rumah sakit Jakarta dan kota di Indonesia menemukan bahwa kurang lebih 50\% dari seluruh pasien yang dirawat di bangsal saraf adalah pasien stroke dan kurang lebih 5\% dari pasien yang dirawat tersebut meninggal karena stroke (3). Survei Riskesdas 2013 melaporkan prevalensi stroke di Indonesia sebesar 12,1 per 1000 penduduk. Sementara prevalensi stroke di Jawa Tengah sebesar 12,3 per 1000 penduduk. Prevalensi stroke pada laki-laki sebesar 12,4 per 1000 penduduk dan perempuan sebesar 12,1 per 1000 penduduk (4).

Selain penyebab kematian, stroke menimbulkan kecacatan jangka panjang. Kecacatan akibat stroke bukan hanya cacat fisik semata, namun juga cacat mental, terutama pada usia produktif (3). Setengah dari pasien yang masih hidup selama tiga bulan setelah stroke akan bertahan hidup lima tahun kemudian, dan sepertiga akan bertahan selama 10 tahun. Sekitar 60\% pasien diharapkan untuk memulihkan kemerdekaan dengan perawatan diri, dan $75 \%$ diharapkan berjalan mandiri. Pasien yang sembuh namun mengalami kecacatan memerlukan bantuan baik oleh keluarga, teman maupun petugas kesehatan. Hal ini diperlukan karena selain dampak kecacatan fisik seperti mobilitas atau keterbatasan aktivitas sehari-hari, dampak lain yang ditimbulkan bagi pasien adalah ketidakmampuan psikososial seperti kesulitan dalam sosialisasi. Dukungan keluarga diharapkan membantu pasien dalam fase rehabilitasi secara optimal sehingga dapat meningkatkan kualitas hidup pasien pasca stroke (1).

Kualitas hidup berkaitan dengan penilaian subjektif tentang status kesehatan seseorang dalam menilai kualitas hidupnya. Kualitas hidup merupakan istilah untuk menyampaikan rasa kesejahteraan, termasuk aspek kebahagiaan dan kepuasan hidup secara keseluruhan (5). Dukungan keluarga yang diberikan kepada pasien selama masa rehabilitasi penting dalam meningkatkan kualitas hidup (6). Kurang kasih sayang, perhatian dan dorongan keluarga dapat menimbulkan penurunan kemampuan dalam beraktivitas (7). Penelitian lain menunjukkan bahwa dukungan sosial yang tinggi akan meningkatkan kesehatan dan mengurangi risiko terkena penyakit (8).

\section{METODE}

Jenis penelitian ini adalah kuantitatif dengan rancangan cross sectional. Penelitian dilaksanakan di RSUD Dr. Soediran Mangun Sumarso pada tanggal 4 Agustus-8 Oktober 2016. Populasi penelitian adalah semua penderita stroke yang sudah di diagnosa oleh dokter dan dirawat $>48$ jam di RSUD Dr. Soediran MS Wonogiri. Besar sampel dalam penelitian dihitung menggunakan rumus correlation coefficient (9).

Sesuai hasil perhitungan diperoleh total sampel adalah 161 responden. Kriteria inklusi adalah pasien stroke iskemik dengan skor BI $<65$, berusia antara 18-60 tahun, dalam keadaan sadar dan mampu berkomunikasi, aktif melakukan rawat jalan, dan bersedia menjadi responden dalam penelitian.

Data dukungan keluarga diperoleh dari wawancara responden menggunakan kuesioner dukungan keluarga yang terdiri dari 36 pertanyaan dengan skala likert (11). Pengukuran kualitas hidup pasien stroke pasca akut menggunakan kuesioner WHO-QOL yang terdiri dari 26 item pertanyaan (12). Data outcome fungsional diperoleh dari rekam medis rumah sakit menggunakan Barthel Indeks (13). Sementara data outcome klinis diperoleh meng- gunakan National Institutes of Health Stroke Scale (NIHSS) (14).

Jenis penelitian ini adalah kuantitatif dengan rancangan cross sectional study. Penelitian ini dilaksanakan di RSUD Dr. Soediran Mangun Sumarso pada tanggal 4 Agustus-8 Oktober 2016. Populasi dalam penelitian ini adalah semua penderita stroke yang sudah di diagnosa oleh dokter dan dirawat $>48$ jam di rumah sakit Dr. Soediran MS Wonogiri. Besar sampel dalam penelitian dihitung menggunakan rumus correlation coefficient (9).

Nilai median dukungan keluarga berupa dukungan emosional, dukungan informasi, dukungan instrumental dan dukungan penghargaan adalah 3. Nilai median kualitas hidup pasien stroke pasca akut adalah 65. Median digunakan sebagai cut off point penilaian dukungan keluarga dan derajat kualitas hidup.

Data diolah dan dianalisis dengan menggunakan software Stata 12.1. Analisis bivariat menggunakan uji Spearman rank dan analisis multivariat menggunakan uji regresi linier ganda dengan kemaknaan statistik $\mathrm{p}<0,05$ dan confidence interval (CI) sebesar 95\%. 


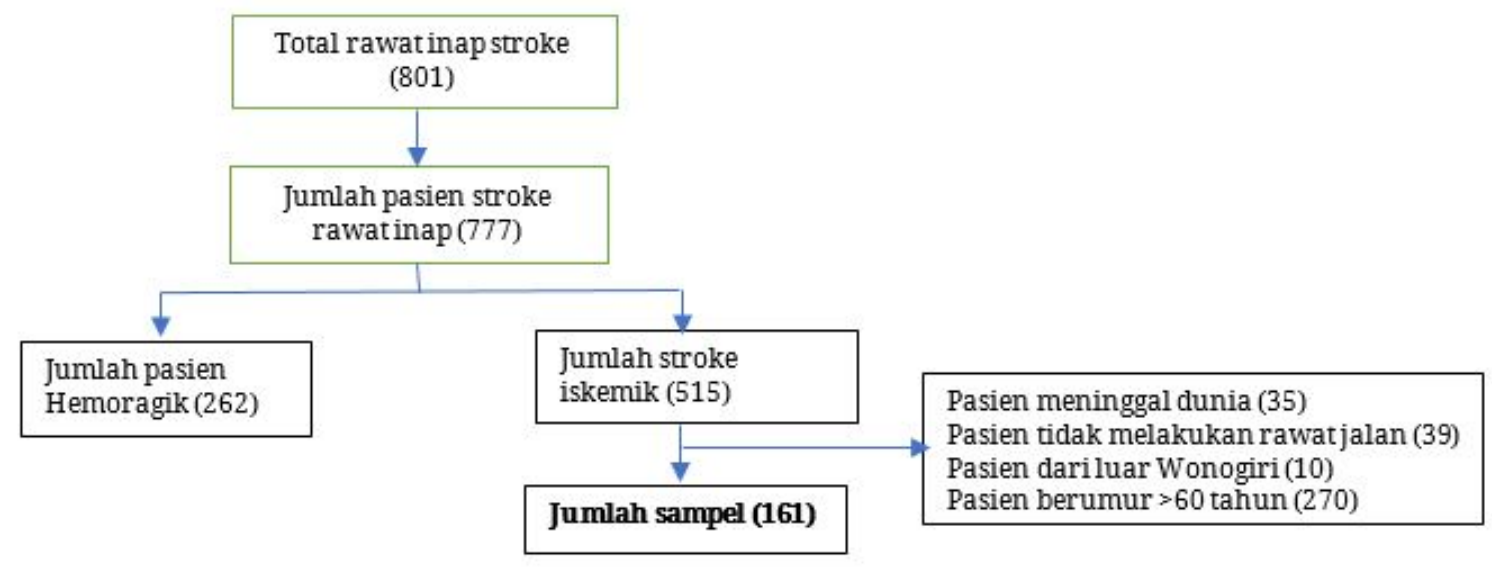

Gambar 1. Cara pengambilan sampel dalam penelitian

\section{HASIL}

Mayoritas responden pada penelitian ini berumur 56-60 tahun, laki-laki, berstatus menikah, pendidikan rendah, bekerja, berstatus ekonomi rendah, bertempat tinggal di wilayah pedesaan, pasien stroke dengan skor barthel indeks antara 50-55 dan pasien stroke dengan skor NIHSS antara 4-14 sebesar. Karakteristik subjek penelitian disajikan dalam Tabel 1.

Tabel 1. Karakteristik pasien stroke pasca akut

\begin{tabular}{lc}
\hline \multicolumn{1}{c}{ Variabel } & \% (n=161) \\
\hline Umur & \\
39-55 tahun (n=40) & 24,84 \\
56-60 tahun (n=121) & 75,16 \\
Jenis Kelamin & \\
Laki-laki (n=90) & 55,9 \\
Perempuan (n=71) & 44,1 \\
Status Perkawinan & \\
Menikah (n=152) & 94,41 \\
Tidak menikah (n=9( & 5,59 \\
Tingkat Pendidikan & \\
Tinggi (n=37) & 22,98 \\
Rendah (n=124) & 77,02 \\
Pekerjaan & \\
Bekerja (n=112) & 69,57 \\
Tidak bekerja (n=49) & 30,43 \\
Status Ekonomi & \\
Tinggi (n=62) & 38,51 \\
Rendah (n=99) & 61,49 \\
Tempat Tinggal & \\
Urban (n=39) & 24,22 \\
Rural (n=122) & 75,78 \\
Barthel Indek & \\
Skor 50-55 (n=87) & 54,04 \\
Skor 30-49 (n=74) & 45,96 \\
NIHSS & \\
Skor 4-14 (n=92) & 57,14 \\
Skor 15-25 (n=69) & 42,86 \\
\hline
\end{tabular}

Tabel 2 menunjukkan lebih dari setengah responden mendapatkan dukungan emosional tinggi, dan mendapat dukungan informasi. Sementara, mayoritas responden memiliki dukungan intrumental dan penghargaan kategori tinggi.

Tabel 2. Distribusi Dukungan Keluarga Penderita Stroke pada Fase Pasca Akut di Kabupaten Wonogiri

\begin{tabular}{lc}
\hline \multicolumn{1}{c}{ Variabel } & Persentase (\%) \\
\hline Dukungan emosional & \\
Tinggi $(\mathrm{n}=90)$ & 55,90 \\
Rendah (n=71) & 44,10 \\
Dukungan Informasi & \\
Tinggi (n=89) & 55,28 \\
Rendah (n=72) & 44,72 \\
Dukungan instrumental & \\
Tinggi (n-81) & 50,31 \\
Rendah (n=80) & 49,69 \\
Dukungan penghargaan & \\
Tinggi (n=86) & 53,42 \\
Rendah (n=75) & 46,58 \\
\hline
\end{tabular}

Tabel 3 menunjukkan responden dengan kualitas hidup tinggi sebanyak 81 (50,31\%). Sedangkan kualitas hidup berdasarkan domain diperoleh: domain fisik tinggi 82 (50,93\%), dimain psikologis tinggi 81 (50,31\%), domain sosial tinggi 83 (51,55\%), domain lingkungan tinggi 84 (52,17\%), persepsi kualitas hidup tinggi 75 $(46,42 \%)$ dan persepsi kesehatan tinggi 75 (46,42\%). Pengaktegorian dilakukan dengan cut off point median pada masing-masing variabel. Nilai cut off median masing-masing variabel disajikan pada bagian Metode. 
Tabel 3. Distribusi skor kualitas hidup penderita stroke pada fase pasca akut di Kabupaten Wonogiri

\begin{tabular}{lc}
\hline \multicolumn{1}{c}{ Variabel } & Persentase (\%) \\
\hline Kualitas hidup & 50,31 \\
Tinggi (n=81) & 49,69 \\
Rendah (n=80) & \\
Domain fisik & 50,93 \\
Tinggi (n=82) & 49,07 \\
Rendah (n=79) & \\
Domain psikologis & 50,31 \\
Tinggi (n-81) & 49,69 \\
Rendah (n=80) & \\
Dukungan Sosial & 51,55 \\
Tinggi (n=83) & 48,45 \\
Rendah (n=78) & \\
Domain Lingkungan & 52,17 \\
Tinggi (n=84) & 47,83 \\
Rendah (n=77) & \\
Persepsi Kualitas hidup & 46,42 \\
Tinggi (n=75) & 53,42 \\
Rendah (n=86) & \\
Persepsi kesehatan & 46,42 \\
Tinggi (n=75) & 53,42 \\
Rendah (n=86) &
\end{tabular}

Tabel 4 menunjukkan variabel yang berhubungan dengan kualitas hidup pasien stroke pada fase pasca akut yaitu dukungan emosional, dukungan informasi, dukungan instrumental dan dukungan penghargaan.

Tabel 4. Korelasi dukungan keluarga pada kualitas hidup pasien stroke fase pasca akut

\begin{tabular}{lcc}
\hline \multicolumn{1}{c}{ Variabel } & $\boldsymbol{r}$ & $\boldsymbol{p}_{\text {-value }} \boldsymbol{v a}^{*}$ \\
\hline Dukungan emosional & 0,801 & 0,0000 \\
Dukungan informasi & 0,795 & 0,0000 \\
Dukungan instrumental & 0,723 & 0,0000 \\
Dukungan penghargaan & 0,766 & 0,0000 \\
\hline Keterangan: *analisis spearman rank (signifikan $\mathrm{p}<0,05)$
\end{tabular}

Keterangan: *analisis spearman rank (signifikan $\mathrm{p}<0,05$ )

Hasil analisis bivariat diketahui bahwa variabel luar yang berhubungan dengan kualitas hidup pasien stroke pada fase pasca akut adalah umur, jenis kelamin, pendidikan, pekerjaan, status ekonomi, barthel indeks, dan NIHSS. Hasil analisis bivariat dapat disajikan pada Tabel 5.

Tabel 5. Korelasi variabel luar dengan kualitas hidup pasien stroke pada fase pasca akut

\begin{tabular}{lcc}
\hline \multicolumn{1}{c}{ Variabel } & $\boldsymbol{r}$ & $\boldsymbol{p}$-value \\
\hline Umur & $-0,309$ & 0,0001 \\
Jenis Kelamin & 0,289 & 0,0002 \\
Status perkawinan & $-0,140$ & 0,0763 \\
Pendidikan & $-0,501$ & 0,0000 \\
Pekerjaan & $-0,372$ & 0,0000 \\
Status Ekonomi & $-0,701$ & 0,0000 \\
Tempat tinggal & $-0,131$ & 0,0964 \\
Barthel Indeks & 0,747 & 0,0000 \\
NIHSS & $-0,734$ & 0,0000 \\
\hline
\end{tabular}

Terdapat 5 variabel yang secara statistik berhubungan dengan kualitas hidup penderita stroke pada fase pasca akut yaitu dukungan informasi, dukungan penghargaan, tingkat pendidikan, barthel indeks dan NIHSS (Tabel 6)

Tabel 6. Analisis multivariat faktor-faktor yang berhubungan dengan kualitas hidup pasien stroke fase pasca akut

\begin{tabular}{lcc}
\hline \multicolumn{1}{c}{ Variabel } & Koefisien $\boldsymbol{b}$ & $\boldsymbol{p}$-value \\
\hline Dukungan informasi & 0,401 & $0,000^{*}$ \\
Dukungan penghargaan & 0,138 & $0,035^{*}$ \\
Pendidikan & $-0,088$ & $0,022^{*}$ \\
Barthel Indeks & 0,278 & $0,000^{*}$ \\
NIHSS & $-0,132$ & $0,025^{*}$ \\
\hline
\end{tabular}

\section{BAHASAN}

Penelitian ini menemukan hubungan dukungan informasi dari keluarga dengan kualitas hidup penderita stroke pada fase pasca akut. Nilai hubungan dukungan informasi keluarga adalah positif, yang berarti semakin meningkat nilai dukungan informasi dari keluarga sebanyak 1 kali maka akan meningkatkan kualitas hidup penderita stroke pada fase pasca akut sebanyak 40\%. Sistem dukungan sosial pada keluarga akan memengaruhi perilaku hidup sehat. Anggota keluarga berperan penting dalam memberikan informasi pencegahan penyakit dan promosi kesehatan serta pemulihan akibat gangguan kesehatan (11). Sumber dukungan informasi adalah keluarga, yang berfungsi sebagai sebuah kolektor dan penyebar informasi. Keluarga merupakan sistem dasar tempat dimana perilaku kesehatan dan perawatan diatur, dilakukan dan dan dijalankan. Anggota keluarga memberikan promosi kesehatan dan perawatan kesehatan preventif, serta berbagai perawatan bagi anggota keluarganya yang sakit (16).

Penelitian ini menemukan hubungan dukungan penghargaan keluarga dengan kualitas hidup penderita stroke pada fase pasca akut. Nilai hubungan dukungan penghargaan keluarga adalah positif, yang berarti semakin meningkat nilai dukungan penghargaan sebanyak 1 kali maka akan meningkatkan kualitas hidup penderita stroke pada fase pasca akut sebanyak $13,8 \%$. rang yang sakit perlu mendapatkan pengakuan dan dukungan dari anggota masyarakat (11). Dukungan penghargaan dari keluarga dapat mening- katkan status psikososial, sehingga mendapat pengakuan atas kemampuan dan keahlian yang dimiliki (16). 
Penelitian menemukan tingkat pendidikan dan kualitas hidup penderita stroke berhubungan negatif. Hal ini menunjukkan bahwa penderita stroke yang kualitas hidup rendah memiliki latar belakang pendidikan tinggi. Sementara penelitian lain menunjukkan bahwa tingkat pendidikan tidak memiliki hubungan dengan kualitas hidup penderita stroke pasca akut $(17,18)$. Penelitian lain menemukan responden yang memiliki pendidikan $\geq 12$ tahun memiliki kualitas hidup yang lebih baik dibandingkan dengan kelompok responden yang memiliki pendidikan $<12$ tahun (19). Seseorang dengan latar belakang pendidikan tinggi lebih matang terhadap proses perubahan yang terjadi, sehingga lebih mudah menerima pengaruh dari luar yang positif, obyektif dan terbuka berbagai informasi tentang kesehatan (20).

Penelitian ini menemukan hubungan yang bermakna secara statistik antara skor barthel indeks seseorang dengan kualitas hidup pasien stroke pada fase pasca akut. Nilai hubungan antara skor barthel indek dengan kualitas hidup diperoleh positif, yang berarti semakin meningkat skor barthel indeks maka akan meningkatkan kualitas hidup penderita stroke sebanyak 27,8\%. Penelitian lain menunjukkan hal serupa, Skor barthel indeks (Fungsional) secara statistik sangat signifikan menurunkan kualitas hidup pasien setelah 6 bulan pasca stroke dengan arah hubungan negatif antara tingkat keparahan stroke (21). Kemampuan pasien saat masuk perawatan berhubungan signifikan dengan kualitas hidup pasien stroke (17). Perbedaan nilai barthel indeks dapat terjadi akibat perbedaan manifestasi, sehingga menyebabkan tingkat ketergantungan yang berbeda pada setiap orang yang menderita stroke. Keterbatasan kemampuan fisik menyebabkan sebagian penderita stroke berfikir negatif dan kurang percaya diri sehingga berisiko meningkatkan keputusasaan. Hal ini dapat menyebabkan penurunan kualitas hidup (22).

Penelitian ini menemukan hubungan negatif bermakna secara statistik antara skor NIHSS seseorang dengan kualitas hidup pasien stroke pada fase pasca akut. Penderita stroke pasca akut yang kualitas hidupnya rendah, lebih membutuhkan perawatan pemulihan kondisi yang lebih tinggi. Penelitian lain menemukan semakin tinggi skor NIHSS (kecacatan), maka kualitas hidup penderita stroke semakin rendah. Pasien stroke dengan cacat parah memiliki kualtas hidup rendah $(21,23)$. Kecacatan akibat stroke, menyebabkan kualitas hidup penderita menjadi rendah. Namun dengan perawatan yang baik, tidak semua pasien yang cacat akibat stroke mengalami ketergantungan. Apabila kecacatan individu dan keter- gantungan dapat dikurangi, maka dapat meningkatkan kualitas hidup penderita stroke (24).

Penelitian ini tidak menemukan hubungan antara dukungan emosional dari keluarga dengan kualitas hidup penderita stroke pada fase pasca akut. Namun, nilai dukungan emosional keluarga adalah negatif, yang berarti semakin meningkat nilai dukungan emosional keluarga maka kualitas hidup pasien stroke pada fase pasca akut semakin rendah. Penelitian ini tidak sejalan dengan Yaslina (2011) menunjukkan bahwa terdapat hubungan antara dukungan emosional berhubungan dengan perawatan pasien pasca stroke (11). Dukungan emosional terkait dengan ekspresi, rasa empati dan perhatian terhadap anggota keluarga sehingga akan menimbulkan perasaan lebih baik, memperoleh kembali keyakinannya, merasa memiliki dan dicintai. Dukungan emosional dapat mengurangi dan mencegah efek stres serta meningkatkan kesehatan individu dan keluarga secara langsung (16).

Responden dengan dukungan instrumental tinggi sebesar 81 (50,31\%) sedangkan responden dengan dukungan instrumental rendah sebesar 80 (49,69\%). Hasil analisis multivariat menunjukkan bahwa tidak terdapat hubungan antara dukungan instrumental dari keluarga dengan kualitas hidup penderita stroke pada fase pasca akut (p-value: 0,173; koefisien b: -0,096). Namun nilai dukungan instrumental keluarga adalah negatif, yang berarti semakin meningkatnya nilai dukungan instrumental dari keluarga maka kualitas hidup pasien stroke pada fase pasca akut semakin rendah. Hal ini tidak sejalan dengan penelitian Yaslina (2011) menunjukkan bahwa terdapat hubungan antara dukungan instrumental dengan perawatan pasien pasca stroke. Keterbatasan fisik yang terjadi pada pasien pasca stroke menyebabkan mereka membutuhkan dukungan keluarga dalam melakukan aktivitas sehari-hari (11).

Dukungan instrumental berupa pertolongan praktis dan kongkrit dari anggota keluarga. Selain itu dukungan instrumental termasuk fungsi perawatan kesehatan keluarga dan fungsi ekonomi yang diterapkan terhadap anggota keluarga yang sakit. Bentuk dukungan instrumental bagi penderita stroke berupa bantuan dalam kebersihan diri, membantu dalam kegiatan MCK, memberikan ketenangan dirumah, penyiapan dana untuk berobat, membantu melakukan latihan pergerakan tubuh, perlindungan terhadap bahaya lingkungan (16).

Hasil analisis multivariat menunjukkan bahwa tidak terdapat hubungan antara umur dengan kualitas hidup dengan penderita pasien stroke pada fase pasca akut. Nilai hubungan menunjukkan bahwa semakin 
bertambah umur seseorang maka kualitas hidup pasien stroke pada fase pasca akut akan semakin menurun. Penelitian ini sejalan dengan Rahmi (2011) menunjukkan bahwa umur tidak berhubungan dengan kualitas hidup pasien stroke (18). Umur merupakan faktor yang memiliki hubungan dengan kualitas hidup pasien enam bulan pasca stroke, dimana semakin meningkatnya usia maka kualitas hidup semakin menurun (21). Kualitas hidup pasien stroke yang berusia $\geq 75$ tahun memiliki kualitas hidup lebih rendah dibandingkan dengan pasien stroke yang berusia 19-64 tahun (25). Usia sangat berhubungan dengan perkembangan status kesehatan pasien serta diidentifikasi sebagai faktor yang berhubungan dengan kemampuan pasien dalam menentukan tindakan dalam memenuhi kebutuhan perawatan diri dan kemampuan untuk merawat diri. Pada usia dewasa, seseorang menggunakan energi sesuai kemampuan untuk menyesuaikan konsep diri dan citra tubuh terhadap realitas fisiologis dan perubahan penampilan fisik. Harga diri yang tinggi, citra tubuh yang bagus dan sikap positif terhadap perubahan fisiologis muncul jika pada usia dewasa menengah mengikuti latihan fisik, diet seimbang, tidur yang adekuat dan melakukan hygiene yang baik sehingga meningkatkan kualitas hidup pasien (11).

Penelitian ini tidak menemukan hubungan jenis kelamin dengan kualitas hidup pasien. Penelitian ini sejalan dengan penelitian sebelumnya yang menunjukkan tidak ada hubungan antara kualitas hidup pasien stroke laki-laki dengan perempuan $(18,19)$. Namun penelitian lain justru menemukan perempuan memiliki kualitas hidup lebih rendah daripada laki- laki. Hal ini disebabkan karena perempuan lanjut usia mengalami stroke lebih parah serta kurang dukungan dari keluarga (21). Jenis kelamin berkaitan dengan beberapa pola kesehatan dan sakit. Dibandingkan laki-laki, perempuan cenderung lebih mudah mengekspresikan penyakit kronik yang dialami (11). Perempuan secara konsisten memiliki lebih banyak informasi kesehatan daripada laki-laki karena peran kesehatan mereka dalam keluarga (16).

Penelitian ini tidak menemukan hubungan bermakna dengan kualitas hidup penderita stroke pada fase pasca akut. Hal ini karena dengan bekerja dapat membantu kondisi keuangan keluarga, selain itu dengan bekerja dapat membantu pada arah pemulihan fisik, meningkatkan rasa percaya diri serta mengurangi depresi. Seseorang yang menderita stroke mengalami cacat dan gangguan sulit untuk memulihkan kondisi fisik sepenuhnya serta akan kehilangan rasa percaya diri. Sehingga sewaktu masa pemulihan, selain pemulihan secara fisik, pemulihan secara psikologis juga penting untuk dilakukan (25).

Penelitian ini tidak menemukan hubungan pekerjaan dengan kualitas hidup penderita stroke pada fase pasca akut. Penderita stroke dengan tingkat ekonomi rendah memiliki kualitas hidup lebih rendah dibandingkan dengan penderita stroke dengan status ekonomi tinggi. Status ekonomi menjadi sangat penting karena dapat membantu mengurangi depresi yang timbul pada pada pasien stroke (25).

Penelitian lain menemukan bukti bahwa responden yang menikah memiliki kualitas hidup lebih baik bila dibandingkan dengan responden yang tidak menikah (duda/janda) (26). Status perkawinan merupakan satu bentuk dukungan sosial terhadap penderita stroke, karena pasangan hidup dapat memberikan dukungan kepada pasangan untuk menjalankan perilaku hidup sehat dan positif (22).

Penelitian ini menemukan hubungan antara tempat tinggal dengan kualitas hidup pasien stroke pada fase pasca akut. Penelitian ini tidak sejalan dengan penelitian sebelumnya yang menunjukkan hubungan antara kualitas hidup penderita stroke dengan tempat tinggal. Penderita stroke yang tinggal di pedesaan (rural) memiliki kualitas hidup lebih rendah dibandingkan dengan oenderita stroke yang hidup di perkotaan (urban). Hal ini disebabkan karena perbedaan tingkat ekonomi antara wilayah rural dan urban, setiap wilayah memiliki masalah kesehatan yang berbeda akibat dari layanan kesehatan yang diberikan karena kondisi geografis, serta sulitnya transportasi dan akses pelayanan kesehatan (25).

Penelitian tentang penyakit kronis di Polandia menunjukkan bahwa terdapat hubungan antara tempat tinggal dengan kualitas hidup penderita penyakit kronis. Pada domain psikologis dan lingkungan, skor lebih tinggi ditemukan pada responden yang tinggal di wilayah pedesaan dibandingkan dengan responden yang tinggal di perkotaan (27).

\section{SIMPULAN}

Dukungan informasi dan dukungan penghargaan adalah faktor yang berhubungan dengan kualitas hidup penderita stroke pada fase pasca akut, sedangkan dukungan emosional dan dukungan penghargaan tidak berhubungan dengan kualitas hidup penderita stroke pada fase pasca akut.

Keluarga perlu aktif membantu penderita dalam beraktivitas sehari-hari, mendengar keluhan, melibatkan dalam musyawarah dan kegiatan keluarga dan 
mencarikan solusi. Perlu promosi edukasi kesehatan tentang dukungan keluarga.

\section{Abstrak \\ Tujuan: Penelitian ini bertujuan untuk mengetahui hubungan dukungan keluarga (emosional, informasi, instrumental dan penghargaan) dengan kualitas penderita stroke pada fase pasca akut di Wonogiri. Metode: Sebuah penelitian cross-sectional dilakukan melibatkan wawancara dan penggunaan data rekam medis 161 penderita stroke pasca akut di Wonogiri. Hasil: Penelitian menunjukkan bahwa terdapat hubungan dukungan informasi, dan dukungan peng- hargaan dengan kualitas hidup penderita stroke pasca akut. Simpulan: Penelitian ini menegaskan pentingnya dukungan keluarga dalam hal dukungan informasi dan penghargaan untuk kualitas hidup pasien dengan stroke pasca-akut.}

Kata Kunci: dukungan keluarga; kualitas hidup; stroke pasca akut

\section{PUSTAKA}

1. World Health Organization. Neurological disorders: public health challenges. World Health Organization; 2006.

2. Kementrian Kesehatan RI. Pedoman Pengendalian Stroke. Direktorat Pengendalian Penyakit Tidak Menular Subdit Pengendalian Penyakit Jantung dan Pembuluh Darah. 2013.

3. Ismail S. Oedem Otak pada Pasien Stroke Iskemik.

4. Kementerian Kesehatan RI. Riset kesehatan dasar. Jakarta: Badan Penelitian dan Pengembangan Kesehatan Departemen Kesehatan Republik Indonesia. 2013.

5. Centers for Disease Control and Prevention. Measuring healthy days: Population assessment of health-related quality of life. Atlanta, GA: Centers for Disease Control and Prevention. 2000 Nov.

6. Laurent K, De Sèze MP, Delleci C, Koleck M, Dehail P, Orgogozo JM, Mazaux JM. Assessment of quality of life in stroke patients with hemiplegia. Annals of physical and rehabilitation medicine. $2011 \mathrm{Sep}$ 1;54(6):376-90.

7. Moon YS, Kim SJ, Kim HC, Won MH, Kim DH. Correlates of quality of life after stroke. Journal of the neurological sciences. 2004 Sep 15;224(1):37-41.

8. Kruithof WJ, van Mierlo ML, Visser-Meily JM, van Heugten CM, Post MW. Associations between social support and stroke survivors' health-related quality of life-a systematic review. Patient education and counseling. 2013 Nov 1;93(2):169-76.

9. Hulley SB, Cummings SR, Browner WS, Grady DG, Newman TB. Designing clinical research. Lippincott Williams \& Wilkins; 2013 May 8.
10. Vincent-Onabajo GO, Muhammad MM, Ali M, Masta M, Aliyu HN. Social support after stroke: Influence of source of support on stroke survivors' health-related quality of life. International Neuropsychiatric Disease Journal. 2016;5:1-9.

11. Yaslina. Hubungan dukungan keluarga, program pemulangan dari rumah sakit dan karakteristik klien dengan perawatan di rumah pada agregat dewasa pasca stroke di Kota Bukit Tinggi. (Universitas Indonesia Depok, 2011.

12. WHOQoL Group. The World Health Organization quality of life assessment (WHOQOL): position paper from the World Health Organization. Social science \& medicine. 1995 Nov 1;41(10):1403-9.

13. Sugeng, A. Pengaruh depresi pasca stroke minggu pertama terhadap Activities of Daily Living penderita stroke di RS Dr. Sardjito (Doctoral dissertation, [Yogyakarta]: Universitas Gadjah Mada).

14. Salter, K. et al. Outcome Measures in Stroke Rehabilitation. www.ebrsr.com 1-144 (2013). at $<$ Http://www.heart.org >

15. Sastroasmoro S, Ismael S. Dasar-dasar metodologi penelitian klinis. Jakarta: Sagung Seto. 2002.

16. Friedman MM, Bowden VR, Jones EG. Buku ajar keperawatan keluarga: Riset, Teori dan Praktek. Jakarta: EGC. 2010:5-6.

17. Cramm JM, Strating MM, Nieboer AP. Satisfaction with care as a quality-of-life predictor for stroke patients and their caregivers. Quality of Life Research. 2012 Dec 1;21(10):1719-25.

18. Rahmi U. Pengaruh discharge planning terstruktur terhadap kualitas hidup pasien stroke iskemik di RSUD Al-Ihsan dan RS Al-Islam Bandung. Universitas Indonesia. 2011.

19. Zalihić A, Markotić V, Mabić M, Černi-Obrdalj E, Zalihić D, Pivić G, Ostojić L. Differences in quality of life after stroke and myocardial infarction. Psychiatria Danubina. 2010 Jun 30;22(2):241-8.

20. Notoatmodjo, S. Ilmu Perilaku Kesehatan. (Rineka Cipta, 2014).

21. Lopez-Espuela F, Zamorano JD, Ramírez-Moreno JM, Jiménez-Caballero PE, Portilla-Cuenca JC, Lavado-García JM, Casado-Naranjo I. Determinants of quality of life in stroke survivors after 6 months, from a comprehensive stroke unit: a longitudinal study. Biological research for nursing. 2015 Oct;17(5):461-8.

22. Ardi M, Sitorus R, Waluyo A. Analisis hubungan ketidakmampuan fisik dan kognitif dengan keputusasaan pada pasien stroke di Makassar. Depok: Universitas Indonesia. 2011.

23. Abubakar SA, Isezuo SA. Health related quality of life of stroke survivors: experience of a stroke unit. International journal of biomedical science: IJBS. 2012 Sep;8(3):183.

24. Chappel, N. L. Age Related Disabilities - Aging and Quality of Life. Cent. Int. Rehbilitation Res. Inf. Excharge;2010..

25. Jun HJ, Kim KJ, Chun IA, Moon OK. The relationship between stroke patients' socio-economic conditions and their quality of life: the 2010 Korean community health survey. Journal of physical therapy science. 2015;27(3):781-4.

26. Baumann M, Lurbe K, Leandro ME, Chau N. Life satisfaction of two-year post-stroke survivors: Effects of socio-economic factors, motor impairment, Newcastle Stroke-Specific Quality of Life measure and World Health Organization 
27. Quality of Life-bref of informal caregivers in Luxembourg and a rural area in Portugal. Cerebrovascular Diseases. 2012;33(3):219-30.
28. Kurpas, D., Mroczek, B. \& Bielska, D. Rural and Urban Disparties in Quality of Life and Health Related Behaviors Among Chronically ill Patients. Rural Remote Health 2014;1-14. 